\title{
PHENOLOGICAL STAGES AND FRUIT QUALITY PARAMETERS OF SOUR CHERRY GENOTYPES IN ROMANIAN CONDITIONS
}

\author{
Margareta Corneanu $^{1}$, Iulia Mineață ${ }^{1 *}$, Elena Iurea ${ }^{1}$, Iuliana-Elena Golache ${ }^{1}$, Sorina Sîrbu ${ }^{1}$ \\ ${ }^{1}$ Research Station for Fruit Growing Iași, România
}

\begin{abstract}
The paper presents some aspects regarding the influence of environmental factors in 2020 on the development and fruiting of local and foreign sour cherry cultivars. Phenological stages, fruit quality traits and other chemical parameters were studied. The swelling of the buds started with March 07 ${ }^{\text {th }}$ ('Tarina'), while the beginning of flowering varied during 11 days, taking place between April 8-19th to April 26th. Fruit's weight have varied between $3.34 \mathrm{~g}$ ('Erdi Ipari`) and $6.28 \mathrm{~g}$ ('Erdi Bibor`), but of the stone between $0.20 \mathrm{~g}$ ('Erdi Ipari') and $0.32 \mathrm{~g}$ ('Erdi Bibor'). Regarding the equatorial diameter, it varied between $16.98 \mathrm{~mm}$ and $22.37 \mathrm{~mm}$ for the varieties 'Erdi Ipari and respectively 'Erdi Bibor'. The fruit ripening took place between June 3rd and 20th. The values of the soluble dry solids recorded data ranging from $13.84 \%$ ('Erdi Korai`) to $17.10 \%$ ('Erdi Bibor '). The studied sour cherry cultivars showed variability, but some were remarked through the size of the fruit and the high level of soluble dry substances, or by the degree of adaptability to the soil and climate conditions in Northeastern Romania.
\end{abstract}

Keywords : bud swelling , Cerasus vulgaris Mill., cultivars, physical characteristics, soluble dry substances.

\section{INTRODUCTION}

From a pomological point of view, the sour cherry (Cerasus vulgaris Mill.) tree is part of the group of stone species and is an intermediate between the parental species Cerasus avium L. and Cerasus fruticosa Pall., having the phenotypic characteristics of its essential biological properties (Dolvog, 2000).

Worldwide, the production of sour cherries is about 11 milion tons, coming mainly from the Eastern Europe, the largest producers of sour cherries being the countries: Turkey, Poland, Russia, Iran, Ukraine, Serbia, Hungary, USA and Romania (FAO, 2015). At the level of Romania, the sour cherries occupies about 5 thousand ha, having a production of about 30 thousand tons yearly and is found in most areas of the country, especially in the hilly area both in industrial plantations and in small areas around households. Traditionally, the fruits are used mainly for industrialization (80\%), in the form of juices, jam or canned cherry (Budan, 2005) but the new targets for sour cherry reproduction include the creation of superior fruit characteristics, resistance to climatic stress, high productivity and mechanical harvesting capacity. Currently, there is a major interest in growing sour cherry for fresh consumption, with larger fruit size, firmness and a pleasant taste. (QueroGarcia, 2017). Despite the variability, there are no configuration that favorably combine the high frost resistance of the sour cherry and the sugary taste of the sweet cherry. The scientific progress registered in the case of fruit research allows that by using modern biotechnological practices to 
overcome some limitations of conventional breeding methods, thus achieving the evolution and diversity of the sour cherry variety, improving qualitative and quantitative properties, increasing production and modern technologies (Branişte et al., 2006).

Local varieties, as well as from abroad, provide enough starting material to ensure that the objectives in terms of physical characteristics (color fruit, fruit weight, diameter, the length of the peduncle) and chemical (soluble dry matter, acidity, sugar content). The sour cherry growing programs in different countries are related to the performance of the traditionally varieties grown in the regions and the new reproductive material is tested in comparison with the standard varieties. (Grafe et al., 2009). The objective of the present study was to evaluate the physico-chemical characteristics of commercially relevant fruits, both local and foreign varieties, grown under conditions in Iasi, Romania.

\section{MATERIALS AND METHODS}

The research took place during the year 2020 at the Research Station for Fruit Growing (RSFG) Iași and targeted six varieties of sour cherries, three local selections 'Timpurii de Pitești', 'Timpurii de Osoi `and 'T Tarina `(Militaru et al., 2018) and three with Hungarian origin `Erdi Ipari ', 'Erdi Bibor', 'Erdi Korai`. (Apostol, 2008), grafted on Prunus mahaleb L. The experimental field is located in northeastern Romania, in Iasi County, where the average annual temperature recorded was $12.1^{\circ} \mathrm{C}$, the normal being $11.33^{\circ} \mathrm{C}$ and rainfall had values of $448.4 \mathrm{~mm}$.

In order to obtain conclusive results regarding the behavior of some sour cherries varieties in ecological conditions, were used as research methods the observation and experiment consisting in: phenological observations, biometric measurements, biochemical and physiological analyzes, techniques of statistical research methods, and took place both in the experimental field and in the laboratory. The phenological observations followed the development of the phenophases of the growth and fruit organs by recording the data according to the landmark stages (Meier et al., 1994): bud swelling, bud burst, beginning of flowering, end of flowering, fruit ripening. The determining factor for phenology stages is the heat, so that, for starting certain phenophases is necessary the cumulative sum of active temperatures (SAT), in the days when it is more than $7^{\circ} \mathrm{C}$. (Cociu and Gozob, 1961). Based on the results obtained, was calculated the value of the coefficient of variation (S\%), which indicates the degree of phenotypic variability depending on the environmental conditions. (Leonte 1997). The biometric measurements performed concerned the physical properties of the fruit: the equatorial diameter, the thickness, the lenght and weight of the fruit and the stone, the length, diameter and weight of the fruit peduncle. The chemical properties included for analysis the determination of the soluble dry solids (SDS\%) content of the fruits. The physical features were performed individually on the fruit. Regarding the equatorial diameter, the measurement was performed in two perpendicular directions of the fruit and the stone, using gauge tool Lumytools and was recorded the average of the values (Radu et al., 1957). The weight of the fruit, the stone and the peduncles was determined by weighing them with the analytical balance Radwag. The soluble dry solids (SDS\%) content was determined using a Zeiss refractometer by adding clear drops of juice to the surface of the refractometer prism. The percentage of soluble substances on the instrument scale was read directly.

The experimental data resulted were statistically interpreted by the Duncan test and coefficient of variation. 


\section{RESULTS AND DISCUSSIONS}

The main studied phenophases of the chosen sour cherry varieties are presented in table 1 . The swelling of the buds started on March $07^{\text {th }}$ for the 'Tarina' variety and ended on March $19^{\text {th }}$ for the 'Erdi Korai variety. Regarding bud burst, the date of this phenophase varied between March 18 and April $4^{\text {th }}$. The sum of the necessary degrees from the phenophase of bud swelling to bud burst had an average value of $91.7^{\circ} \mathrm{C}$ and a coefficient of variation of $16.87 \%$. The beginning of flowering took place starting with April $8^{\text {th }}$ and $9^{\text {th }}$ for the local varieties and the sum of the necessary degrees from budding to the beginning of flowering was on average $129.72^{\circ} \mathrm{C}$. The flowering phenophase from its beginning to the end, lasted 8 ('Erdi Korai' and 'Erdi Ipari') to 16 days ('Țarina'). The sum of the degrees required from the beginning to the end of flowering recorded the average value of $136.02^{\circ} \mathrm{C}$, with a minimum of $81.6^{\circ} \mathrm{C}$ and a maximum of $177.9^{\circ} \mathrm{C}$. The coefficient of variation between these two phenophases was $29.67 \%$.

Buds and flower development is influenced by plant age and healthiness, position and density in the shoot, climatic conditions, geographical area, agrotechnical methods and usage of pesticides (Szalay, 2006).

Table 1. Sum of active temperatures $(\mathrm{SAT})\left(\geq 7^{\circ} \mathrm{C}\right)$ required for the beginning of sour cherry phenophases (RSFG Iași, 2020)

\begin{tabular}{|c|c|c|c|c|c|c|c|c|c|c|}
\hline \multirow[t]{2}{*}{ Cultivars } & $51 *$ & $53 *$ & $\begin{array}{c}\text { from } 51 \\
\text { to } 53\end{array}$ & $\Sigma^{\mathrm{T}}$ & $61 *$ & $\begin{array}{c}\text { from } 53 \\
\text { to } 61\end{array}$ & $\Sigma^{T}$ & $69 *$ & $\begin{array}{c}\text { from } 61 \\
\text { to } 69\end{array}$ & $\Sigma^{T}$ \\
\hline & (data) & (data) & (days) & $\left({ }^{\circ} \mathrm{C}\right)$ & (data) & (days) & $\left({ }^{\circ} \mathrm{C}\right)$ & (data) & (days) & $\left({ }^{\circ} \mathrm{C}\right)$ \\
\hline Timpurii de Pitești & 09.03 & 18.03 & 10 & 102.2 & 09.04 & 14 & 117.5 & 22.04 & 14 & 151.7 \\
\hline Timpurii de Osoi & 09.03 & 23.03 & 14 & 112.9 & 09.04 & 18 & 109.0 & 22.04 & 14 & 141.9 \\
\hline Țarina & 07.03 & 27.03 & 21 & 74.0 & 08.04 & 14 & 141.0 & 23.04 & 16 & 177.9 \\
\hline Erdi Ipari & 13.03 & 30.03 & 18 & 96.8 & 15.04 & 17 & 133.2 & 22.04 & 8 & 81.6 \\
\hline Erdy Bibor & 13.03 & 27.03 & 15 & 74.6 & 13.04 & 18 & $157, .5$ & 26.04 & 14 & 170.9 \\
\hline Erdy Korai & 19.03 & 04.04 & 17 & 89.5 & 19.04 & 16 & 180.1 & 26.04 & 8 & 92.1 \\
\hline Min & & & 10 & 74.00 & & 14 & 109.0 & & 8 & 81.60 \\
\hline Max & & & 21 & 112.9 & & 18 & 180.10 & & 16 & 177.9 \\
\hline Average & & & 15.83 & 91.67 & & 16.17 & 139.72 & & 12.33 & 136.02 \\
\hline STDEV & & & 3.76 & 15.47 & & 1.83 & 26.18 & & 3.44 & 40.35 \\
\hline COVAR S\% & & & 23.77 & 16.87 & & 11.35 & 18.74 & & 27.93 & 29.67 \\
\hline
\end{tabular}

*BBCH-Phenological growth stages (Meier et al., 1994): 51 (buds swelling); 53 (bud burst); 61 (beginning of flowering: about 10\% of flowers open); 69 (end of flowering).

Regarding the degree of adaptability of the sour cherry varieties studied to the ecological conditions in Iasi, biometric measurements of the physical and chemical characteristics of the fruit were performed such as: weight, diameter, thickness, height and soluble dry matter content. The centralized averages were statistically interpreted and presented in table 2 . Regarding the weight of the fruit, the significant differences were between the local varieties ('Timpurii de Pitești', 'Timpurii de Osoi', 'Țarina') and the foreign ones ('Erdi Bibor', 'Erdi Korai'), this varying between $3.38 \mathrm{~g}$ ('Erdi Ipari') and $6.29 \mathrm{~g}$ for the variety 'Erdi Bibor'. The diameter and height had statistically insignificant values for the varieties 'Timpurii de Pitești', 'Timpurii de Osoi', 'Țarina', having similar values, while the varieties with Hungarian origin, have significant differences between the 'Erdi Ipari variety and the other two ('Erdi Bibor' and 'Erdi Korai'). Regarding the soluble dry solids content (SDS\%), the average values had a minimum of $13.87 \%$ for the 'Erdi 
Korai cultivar and a maximum of $17.26 \%$ for the 'Erdi Bibor'. Interpreted statistically, there were significant differences in the 'Erdi Bibor' and 'Erdi Ipari cultivars compared to the rest of the sour cherry varieties studied. The weight and diameter of all the cultivars are in correlation with the standard dimensions according to Apostol (2008) and Ștefan (2018).

Table 2. Physical and chemical characteristic of the fruit in the investigated sour cherry cultivars (RSFG Iași, 2020, $n=3$ )

\begin{tabular}{c|ccccc}
\hline Cultivar & Weight $^{*}(\mathbf{g})$ & $\begin{array}{c}\text { Equatorial } \\
\text { diameter* }^{*}\end{array}$ & $\begin{array}{c}\text { Thickness* }^{*} \\
(\mathbf{m m})\end{array}$ & Length* $^{*}(\mathbf{m m})$ & SDS\% $^{*}$ \\
\hline Timpurii de Pitești & $4.37^{\mathrm{b}}$ & $19.09^{\mathrm{b}}$ & $16.74^{\mathrm{b}}$ & $16.27^{\mathrm{b}}$ & $14.53^{\mathrm{b}}$ \\
Timpurii de Osoi & $4.42^{\mathrm{b}}$ & $19.09^{\mathrm{b}}$ & $16.79^{\mathrm{b}}$ & $16.09^{\mathrm{b}}$ & $14.6^{\mathrm{b}}$ \\
Țarina & $4.46^{\mathrm{b}}$ & $19.18^{\mathrm{b}}$ & $17.05^{\mathrm{b}}$ & $16.66^{\mathrm{b}}$ & $14.01^{\mathrm{b}}$ \\
Erdi Ipari & $3.38^{\mathrm{c}}$ & $17.11^{\mathrm{c}}$ & $14.81^{\mathrm{c}}$ & $15.18^{\mathrm{c}}$ & $15.83^{\mathrm{ab}}$ \\
Erdi Bibor & $6.29^{\mathrm{a}}$ & $22.44^{\mathrm{a}}$ & $19.58^{\mathrm{a}}$ & $19.59^{\mathrm{a}}$ & $17.26^{\mathrm{a}}$ \\
Erdi Korai & $5.98^{\mathrm{a}}$ & $22.12^{\mathrm{a}}$ & $17.92^{\mathrm{b}}$ & $19.91^{\mathrm{a}}$ & $13.87^{\mathrm{b}}$ \\
\hline
\end{tabular}

*different letters indicate the statistical difference in rows.

In order to establish the character of the fruit of a cultivar, the biometric characteristics of the stone and the peduncle were analysed in table 3. Regarding the weight of the stone, the average values varied between $0.2 \mathrm{~g}$ and $0.32 \mathrm{~g}$ for the 'Erdi Ipari 'variety and the 'Erdi Bibor', respectively. The statistical differences were significant for all cultivars. The equatorial diameter of the stone has insignificant differences between the varieties 'Timpurii de Osoi', 'T,arina', 'Erdi Bibor', 'Erdi Korai, with close values on average of $8.6 \mathrm{~mm}$. The thickness varied between the minimum of 6.17 $\mathrm{mm}$ and the maximum of 7.59, with significant values between varieties. The stone length also has significant differences, with dimensions between $8.12 \mathrm{~mm}$ and $10.84 \mathrm{~mm}$. The peduncle sizes of the varieties varied from $23.88 \mathrm{~mm}$, for the 'Timpurii de Osoi' variety and $37.35 \mathrm{~mm}$ for 'Țarina'. The differences recorded are significant between all cultivars.

Table 3. Physical features of the stone and peducle of the fruit in the investigated sour cherry cultivars (RSFG Iași, 2020, $n=3$ )

\begin{tabular}{c|cccc|ccc}
\hline \multirow{2}{*}{ Cultivar } & \multicolumn{4}{|c|}{ Stone } & \multicolumn{3}{c}{ Peduncle } \\
\cline { 2 - 8 } & $\begin{array}{c}\text { Weight* } \\
(\mathbf{g})\end{array}$ & $\begin{array}{c}\text { Equatorial } \\
\text { diameter* } \\
(\mathbf{m m})\end{array}$ & $\begin{array}{c}\text { Thickness* } \\
(\mathbf{m m})\end{array}$ & $\begin{array}{c}\text { Length* } \\
(\mathbf{m m})\end{array}$ & $\begin{array}{c}\text { Length* } \\
(\mathbf{m m})\end{array}$ & $\begin{array}{c}\text { Diameter* } \\
(\mathbf{m m})\end{array}$ & $\begin{array}{c}\text { Weight* } \\
(\mathbf{g})\end{array}$ \\
\hline Timpurii de Pitești & $0.24^{\mathrm{bcd}}$ & $7.97^{\mathrm{bc}}$ & $7.09^{\mathrm{bc}}$ & $9.04^{\mathrm{cd}}$ & $26.2^{\mathrm{de}}$ & $1.2^{\mathrm{a}}$ & $0.08^{\mathrm{bc}}$ \\
Timpurii de Osoi & $0.22^{\mathrm{cd}}$ & $8.67^{\mathrm{ab}}$ & $7.23^{\mathrm{b}}$ & $8.71^{\mathrm{d}}$ & $23.88^{\mathrm{e}}$ & $1.31^{\mathrm{b}}$ & $0.08^{\mathrm{c}}$ \\
Țarina & $0.26^{\mathrm{bc}}$ & $8.08^{\mathrm{abc}}$ & $7.16^{\mathrm{bc}}$ & $9.6^{\mathrm{b}}$ & $37.35^{\mathrm{a}}$ & $1.09^{\mathrm{d}}$ & $0.11^{\mathrm{a}}$ \\
Erdi Ipari & $0.2^{\mathrm{d}}$ & $7.39^{\mathrm{c}}$ & $6.17^{\mathrm{d}}$ & $8.12^{\mathrm{e}}$ & $29.68^{\mathrm{cd}}$ & $0.83^{\mathrm{af}}$ & $0.05^{\mathrm{de}}$ \\
Erdi Bibor & $0.32^{\mathrm{a}}$ & $9.02^{\mathrm{a}}$ & $7.59^{\mathrm{a}}$ & $10.84^{\mathrm{a}}$ & $32.92^{\mathrm{bc}}$ & $0.89^{\mathrm{e}}$ & $0.05^{\mathrm{e}}$ \\
Erdi Korai & $0.28^{\mathrm{ab}}$ & $8.61^{\mathrm{ab}}$ & $6.88^{\mathrm{c}}$ & $10.67^{\mathrm{a}}$ & $36.12^{\mathrm{ab}}$ & $1.1^{\mathrm{cd}}$ & $0.1^{\mathrm{a}}$ \\
\hline
\end{tabular}

*different letters indicate the statistical difference in rows.

However, the results recorded in the studied sour cherry varieties are similar to other research on these genotypes. The dimensions of the peduncle had values acording to Davarynej et al., (2009) who researched the new and old sour cherry cultivars in Hungarian climatic conditions. 


\section{CONCLUSIONS}

- The evolution of the phenological stages is determined by the plant genotype, but the environmental conditions can cause significant fluctuations of the traits in the varieties. The results shows a high morphological variability of fruit traits between local selections and those with Hungarian origin. All genotypes have a similar phenological stage, with a period of early to medium flowering and maturation.

- The attributes of physical and chemical quality of the fruits from the studied sour cherry varieties showed that the foreign varieties adapted to the ecological conditions in Iași, keeping their specific characteristics of the cultivar. Of these varieties, 'Erdi Bibor` has stood out for its fruit size and high soluble dry solid content.

- The development of the phenological stages and the physical and chemical parameters observed showed that all the sour cherry varieties studied can be used for both fresh and processed consumption.

\section{REFERENCES}

Apostol, J. (2008). New sweet and sour cherry selections in Hungary. Acta Horticulturae. 795, 75-78.

Braniste, N. et al. (2006). Fondul de germoplasma la speciile pomicole, arbusti fructiferi si capsun din colectiile din Romania [Germplasm fund for fruit species, fruiting shrubs and strawberries from Romanian collections], Editura Pamântul, Pitesti. pp. 93-117.

Budan, S., Mutafa, I., Stoian, I., Popescu, I. (2005). Screening of 200 sour cherry genotypes for Monilia laxa field resistance. Acta Horticulturae 667:145-151.

Cociu, V., Gozob, T. (1961). Observațiuni asupra biologiei înfloritului la vișin, Lucrări științifice I.C.H.V.,vol IV [Observations on the biology of sour cherry blossoms, Scientific papers I.C.H.V., vol IV], 5: 293-303

Davarynej, G.H., Nyéki J., Szabó, T., Tornyai, J., Soltész M., Aryanpooya Z., Szabó Z. (2009). First evaluation of fruit quality of some new and old sour cherry cultivars in Hungarian climatic condition, International Journal of Horticultural Science, Agroinform Publishing House, Budapest, 15(4): 37 -43.

Dolgov, S.V. (2000).Genetic Transformation of sour cherry (Cerasus vulgaris Mill.). Biotechnology in Agriculture and Forestry, vol 44. Springer, Berlin, Heidelberg

Grafe, C., Höfer, M., Schuster, M. (2009).Evaluation of dry matter in sour cherry (Prunus cerasus L.). Acta Horticulturae. 839, 281-286.

Leonte, C.(1997). Ameliorarea plantelor horticole și tehnică experimentală [Improvement of horticultural plants and experimental technique], Ed. Ion Ionescu de la Brad, Iași, pp. 21

Meier, U. (1994). BBCH-Monograph. Growth stages of plants., Federal Biological Research Centre for Agriculture and Forestry, Braunschweig

Militaru, M., Coman, M., Butac, M., Sturzeanu, M., Tititrică, I., Călinescu, M., Stanciu, C., Botu, M., Gavăț, C., Sîrbu, S., Iurea, E., Erculescu, M., Sestraș, A. (2018). Fondul de germoplasmă la speciile pomicole cultivate în România.[ Germplasm fund for fruit species cultivated in Romania] Ed. Invel, pp. 210

Quero-Garcia, J., Iezzoni, A., Pulawska, J., Lang, G.A. (2017). Cherries: Botany, Production and Uses, CABI, Boston, 95-114

Radu, I.F., Pandele, I., Enăchescu, G. (1957). Proprietatile fizice, chimice si tehnologice ale fructelor principalelor specii pomicole cultivate in R.P.R. [Physical, chemical and technological properties of the fruits of the main fruit species cultivated in R.P.R],București, Editura Academiei Republicii, pp.256

Szalay, L. (2006). Comparison of flower bud development in almond, apricot and peach genotypes. International Journal of Horticultural Science, 12 (2): 93-98

Ștefan, N., Glăman, G., Braniște, N., Stănică, F., Duțu, I., Coman M. (eds.) (2018). Pomologia României X [Romanian Pomology X]. Bucharest, RO: Ceres Publishing House, 705-715

http://www.fao.org/faostat/en/\#data/QC, 15.03.2021 